Review

\title{
Tropical Food Spices: A Promising Panacea for the Novel Coronavirus Disease (COVID-19)
}

\author{
Adedayo O. Ademiluyi ${ }^{1}$, (i) , Olubukola H. Oyeniran ${ }^{1,2, *}, \mathbb{D}^{\mathbb{D}}$, Ganiyu Oboh $^{1}$ \\ ${ }^{1}$ Functional Foods, Nutraceuticals and Phytomedicine Unit, Department of Biochemistry, Federal University of Technology, Akure 340001, Nigeria \\ ${ }^{2}$ Department of Biochemistry, Federal University Oye - Ekiti P.M.B. 373, Ekiti State, Nigeria
}

\section{ARTICLE INFO}

\section{Article History}

Received 20 August 2020

Accepted 20 October 2020

\section{Keywords}

COVID-19

SARS-CoV-2

respiratory infections

ACE2

spices

antivirals

\section{ABSTRACT}

Coronavirus disease 2019 (COVID-19) is an infectious fatal disease caused by the Severe Acute Respiratory Syndrome Coronavirus-2 (SARS-CoV-2) with millions of individuals infected globally within few months of its outbreak. During infection, the SARS-CoV-2 main protease binds directly to Angiotensin-converting Enzyme 2 (ACE2) receptor of the human host cells, most especially in the lungs where it replicates and causes respiratory infections. Currently, there is neither universally recommended nor approved treatment for the morbid disease caused by this virus. Therefore, the urgent need for therapy has led to the use of medicinal plants such as tropical food spices which have been previously used as antivirals. Thus, this review described the coronaviruses, the causative virus of COVID-19, the role of ACE2 in SARS-CoV-2 infection, health complications in COVID-19, the general importance of tropical spices, the potential beneficial role of tropical spices as potent inhibitors of SARS-CoV-2 and the mechanisms of action of some selected tropical spices: turmeric, onion, garlic, red chille pepper, black pepper and cinnamon; based on prior knowledge of their medicinal values. This might help to promote the use of spices and/or their isolated compounds as functional foods, nutraceuticals and potent alternative medicines to provide fast optimal relief or cure for COVID-19.

\section{GRAPHICAL ABSTRACT}

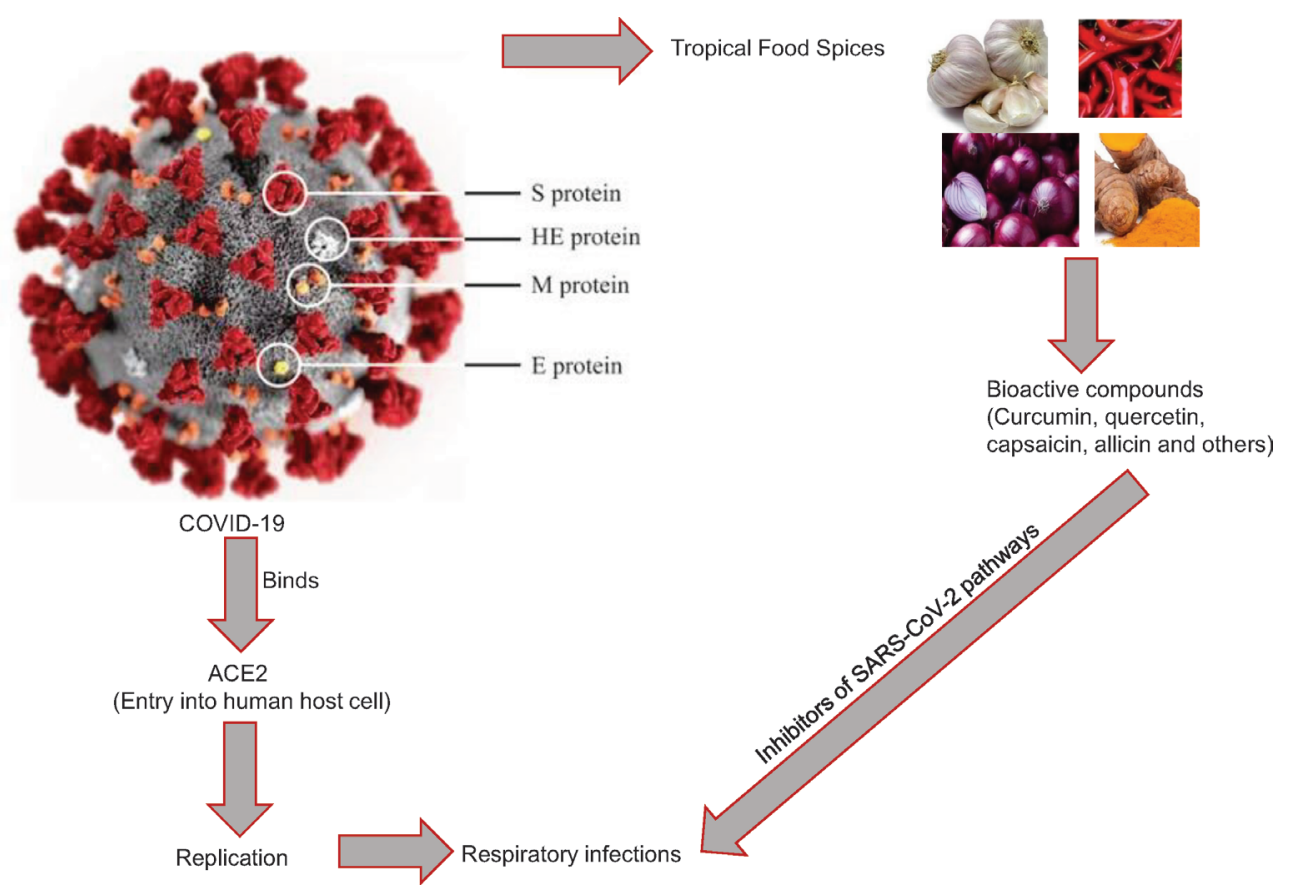

(C) 2020 The Authors. Publishing services by Atlantis Press International B.V. This is an open access article distributed under the CC BY-NC 4.0 license (http://creativecommons.org/licenses/by-nc/4.0/).

CCorresponding author. Email: olubukola.oyeniran@fuoye.edu.ng; oyeniranolubukola@ gmail.com

Peer review under responsibility of the International Association of Dietetic Nutrition and Safety 


\section{INTRODUCTION}

The outbreak of the novel Coronavirus Disease 2019 (COVID-19) was firstly reported in Wuhan, China in December 2019 and spreading speedily to nearly every country of the world. It became a public health emergency of international concern on 30th January, 2020 and a global health pandemic by World Health Organization (WHO) on 11th March, 2020 [1,2]. This disease infects people of all ages and races, however, older people (40 years and above) and individuals with underlying medical conditions (e.g. cardiovascular disease, diabetes, chronic respiratory disease, cancer etc.) are more vulnerable and may get worse because of its deadly complications, most especially, multiple organ failure. As at 25th July, 2020, the outbreak has escalated to over 15.8 million cases with about 641,243 deaths being confirmed and reported globally. This disease is caused by the Severe Acute Respiratory Syndrome Coronavirus-2 (SARS-CoV-2), studies had established that SARS-CoV-2 had similar sequence with the SARS$\mathrm{CoV}$ and bat coronavirus which were earlier reported [3]. During infection, the SARS-CoV-2 main protease and spike glycoprotein binds directly to Angiotensin-converting Enzyme 2 (ACE2) receptor of the human host cells, most especially in the lungs where it replicates and causes respiratory infections [4]. Presently, there is neither universally recommended nor approved treatment for the morbid disease caused by this virus. Thus, to develop therapy, it is expedient to have a thorough understanding of the basic mechanism of pathogenicity. In the interim, researchers are working very hard on how to provide safe and natural alternative medicines to the public before making available a specific drug or vaccine in a timely fashion [5].

The current available therapies are antiviral, antibiotic, antimalarial and anti-inflammatory drugs including monoclonal antibodies [6-8]. Previous studies had explained the importance of medicinal plants over synthetic drugs in various diseases conditions, a lot of this medicinal plants such as tropical spices possess anti-infective, antiviral, anti-inflammatory, antimalarial and antioxidant properties [9-11]. About $49 \%$ of all natural products molecules or derivatives approved for human use by the US Food and Drug Administration have been linked directly to spices [12]. The consumption of spices is very high in the tropics, coincidentally, these spices are not consumed singly but often combined to produce significant health effects. Previous studies had indicated that spices possess phenolic-rich constituents which provides the molecular basis for their added medicinal benefits $[11,12]$. The potency of isolated compounds from some Indian spices as inhibitors of SARS-CoV-2 main protease has been tested recently [13], therefore, it is expedient to consider tropical spices as a promising panacea for COVID-19. Here, we described the coronaviruses, the causative virus of COVID-19, the role of ACE2 in SARS-CoV-2 infection, health complications in COVID-19, the potential beneficial role of tropical spices as potent inhibitors of SARS-CoV-2 and the mechanisms of action of some selected tropical spices: turmeric, onion, garlic, red chille pepper, black pepper and cinnamon; based on prior knowledge of their medicinal values.

\section{BRIEF DESCRIPTION OF CORONAVIRUS}

Coronaviruses are important pathogens which cause respiratory and enteric diseases in mammals and some birds. They are singlestranded RNA viruses that belong to the Kingdom Riboviria, Family Coronaviridae, Subfamily Coronavirinae and Order Nidovirales [14,15]. They are classified into four genus which include Alpha, Beta, Gamma and Delta. It is believed that the Alpha and Beta coronaviruses came to existence from bats while Gamma and Delta coronaviruses are thought to have emerged from birds and pigs [16]. About 39 different species have been identified, most of these species are enzootic with just only a few causing disease in humans [17]. The human coronaviruses affects the respiratory tract and cause mild-to-moderate illnesses which include common flu and cold. Almost all the human population comes into contact with these viruses at a particular time [18]. At present, the Human Coronaviruses (HCoVs) include $\mathrm{HCoV}-229 \mathrm{E}, \mathrm{HCoV}-\mathrm{OC} 43$, HCoV-NL63, HCoV-HKU1, SARS-CoV, SARS-CoV-2 and Middle East Respiratory Syndrome Coronavirus (MERS-CoV) [19,20]. The HCoV-229E and HCoV-NL63 belong to the Alpha-coronaviruses while the remaining $\mathrm{HCoVs}$ are Beta coronaviruses. The $\mathrm{HCoV}$ 229E, HCoV-NL63, HCoV-HKU1 and HCoV-OC43 strains of coronavirus give rise to moderate respiratory diseases in humans while SARS-CoV and MERS-CoV are among the pathogens included in the WHO's list of high-priority threats [21,22] with the capability to cause severe pneumonia [23]. The sudden emergence of a new pathogenic virus reported in 2019 and the Coronavirus Study Group of the International Committee on Taxonomy of Viruses named the virus as SARS-CoV-2 [15]. This followed the emergence of its antecedent virus named SARS-CoV in 2002. The outbreak of this viral infection affected the human population for about a year, spreading across 37 countries of the world with over 8000 reported infected cases and almost 800 deaths $[24,25]$.

\section{SEVERE ACUTE RESPIRATORY SYNDROME CORONAVIRUS-2}

The SARS-CoV-2 belongs to the genus Beta-coronavirus and under the species SARS-related coronaviruses. They belong to group $2 \mathrm{~B}$ and shares $70 \%$ similarity in genetic sequence with SARS-CoV [26] and $96.2 \%$ sequence homology with the bat coronavirus [27]. It is the seventh isolated coronavirus species with ability to cause disease in human. They had identified two strains of this virus, the 'L' and ' $\mathrm{S}$ ' strains; the 'L' strains are more common and they probably emerged from 'S' strain. The genomic formation and adaptive nature of this virus are not well understood by researchers due to its high rate of mutation [28]. However, symptoms from this virus progress slowly over an incubation period of about 14 days and the virus replicates in the upper and lower respiratory tracts during this time [29]. Generally, the symptoms observed during this infection are fever, cough, breathing difficulty and lungs lesion [30]. Furthermore, these symptoms progress to life-threatening respiratory disorder in its advanced stage [31]. Reports have also shown that this virus could induce neurological disorders in patients [32,33]. Moreover, some infected persons are asymptomatic with such individuals unknowingly spreading the virus and thus posing a substantial difficulty for the virus to be contained. Consequently, governing authorities of most nations of the world have made rules that minimize human contact, e.g. social distancing and impromptu shutdown of public places [5].

\subsection{Role of Angiotensin-converting Enzyme 2 in SARS-CoV-2 Infection}

The SARS-CoV-2 possesses positive-single stranded enveloped RNA viruses (+ssRNA) with genome size of about 27-32 kilobases 
[34]. The main protease of SARS-CoV-2 is mainly involved in polyprotein processing, they contain four important structural and functional proteins, these are: envelope protein (E), membrane protein (M), spike protein (S) and nucleocapsid protein (N) [17]. The E protein is involved in the development of capsid and the whole viral structure and the virus attaches to the host cells using $M$ protein $[35,36]$. The transmembrane $S$ protein glycol possess three main divisions which anchors host cells, these are: large ectodomain (this consist of S1 receptor-binding and S2 membrane fusion subunits), single-pass transmembrane anchor and short intracellular tail [37]. SARS-CoV-2 main protease has at least 11 cleavage sites where viral replication and toxicity takes place. The viral genome has two kinds of receptors, these are: the receptor binding domain and Receptor Binding Motif (RBM) [38-40]. The RBM of S protein binds directly to ACE2 in host cells, this is a vital event in the cellular entry of SARS-CoV-2 on the respiratory tract epithelium of infected patient [41]. The RBM of SARS-CoV-2 has a major amino acid residue (Glutamine 493) that favors its attachment and fusion with the ACE2 protein of the human cell, most especially, the lungs and thus, causing respiratory infections in humans $[38,42]$. Thus, the inhibition of these viral targets might prevent the binding and replication of SARS-CoV-2.

Angiotensin-converting enzyme 2 protein is an important component of the Renin-Angiotensin-Aldosterone System (RAAS). It is a type I integral membrane glycoprotein with an N-terminal extracellular domain which comprises two $\alpha$-helical lobes having a catalytic site with a coordinated zinc ion between the lobes [24]. This enzyme is produced in several human organs, but prominent in the lungs, kidney, heart, endothelium, gut, central nervous system and intestine $[43,44]$. It plays a critical role in regulating blood pressure, inflammation and fibrosis, thus, they mediates heart failure, hypertension, myocardial infarction, diabetic cardiovascular complications and chronic kidney diseases [45,46]. ACE2 catalyzes the conversion of angiotensin I and II into angiotensin 1-9 and angiotensin $1-7$, respectively $[45,47]$, the latter acts at the Mas receptor [48]. Angiotensin (1-7) promotes vasodilation, sodium and water excretion, reduce sympathetic nervous system tone and increase nitric oxide production [49-51]. Therefore, the inhibition of the ACE2 protein is absolutely paramount to reduce the binding of the host receptor to SARS-CoV-2 and consequently results in the prevention and treatment of COVID-19 [52-54]. Thus, agents with ACE2 protein inhibitory properties might be a promising panacea and novel therapy for COVID-19 treatment [55-57].

\section{HEALTH COMPLICATIONS IN COVID-19}

Coronavirus disease 2019 patients often develop respiratory symptoms such as pneumonia coupled with accelerated organ damage which causes multiple organ failure at the advanced stage of the disease. These conditions are partly driven by sustained increased inflammatory cytokine and are the most notable cause of death in infected patients. In addition, heart and kidney structural damages coupled with abnormalities in heart, gut and liver functions are also involved. All these suggest ongoing systemic manifestation of myocardial, renal, enteric and hepatic damages [34,46,58]. Altered RAAS and ACE2 coupled with SARS-CoV-2 infection in the cardiovascular system is reflected through incidences of acute myocardial injury, arrhythmias, cardiac arrest, sepsis, septic shock, viral myocarditis and heart failure [59,60]. In fact, altered levels of ACE2 was reported in individuals with gut dysbiosis and diabetes $[61,62]$. Furthermore, the expression of ACE2 in luminal surface of the enterocytes in Gastrointestinal Tract (GIT) provides an alternate route for enteric SARS-CoV-2 infection. Duan et al. [62] and Hashimoto et al. [63] demonstrated that leaky GIT in experimental models were improved or made worse depending on the levels of ACE2 protein. This may likely be responsible for the GIT discomfort and diarrhea reported in some COVID-19 infected patients coupled with the presence of viral RNA in their faeces $[64,65]$. Moreover, tissue and systemic inflammation occurs due to altered ACE2 which causes the up-regulation of inflammatory cytokines such as interferon- $\gamma$, interleukin- 6 and chemokine [4,58]. Thus, people with pre-existing ailments such as hypertension, diabetes, respiratory, inflammatory and gastrointestinal disease are all at higher risk of COVID-19 infection [66].

\section{GENERAL IMPORTANCE OF TROPICAL SPICES}

Spices are natural plants or vegetable products or their mixtures in whole, crushed or powdered form which serves as esoteric food adjuncts or additives and majorly used as flavors, colorants, preservatives and sometimes as aroma and palatability enhancers $[11,67,68]$. The distinctive scents of virtually all spices can be detected on the breath following oral ingestion. The classification of spices depend on their origin, the active principle present in them or the parts used [69]. The basic classification of spices and few examples in each category are presented in Table 1.

The pictures of some common tropical spices is depicted in Figure 1. The various spices are often mixed with diets containing cereals, legumes, nuts, fruits, vegetables, milk and milk products. They also serve as basic ingredients in preparing soup with ability to improve nutritional benefits of food and/or food products. However, spices are not among the suggested food groups required to get balanced diets [70]. Beside their nutritional importance, they could also provide added significant medicinal values. Many studies have reported that spices possess phenolic-rich constituents which provides the molecular basis for their added medicinal benefits $[11,71,72]$. The chemical structures of major phenolic compounds

Table 1 Basic classification of spices with examples

\begin{tabular}{|c|c|}
\hline Classes & Examples \\
\hline Pungent spices & Pepper, ginger, chillies and mustard \\
\hline Aromatic fruits & $\begin{array}{l}\text { Cardamom, nutmeg, coriander, } \\
\text { fenugreek and aniseed }\end{array}$ \\
\hline Aromatic barks & Cinnamon and cassia \\
\hline Eugenol containing spices & Clove and pimento \\
\hline Colored spices & Turmeric, saffron and paprika \\
\hline $\begin{array}{l}\text { Leaves and/or branches of } \\
\text { and chervil }\end{array}$ & $\begin{array}{l}\text { Basil, bay leaf, parsley, rosemary, } \\
\text { tarragon and thyme, oregano } \\
\text { aromatic plants }\end{array}$ \\
\hline Ripened fruits or seeds of plants & $\begin{array}{l}\text { Dill, fennel, coriander, fenugreek, } \\
\text { berberis and black pepper }\end{array}$ \\
\hline Roots or bulbs of certain plants & $\begin{array}{l}\text { Garlic, onion, celery, turmeric } \\
\text { and ginger }\end{array}$ \\
\hline
\end{tabular}

This table represents the classification of spices based on their origin, the active principle present in them or the parts used. 

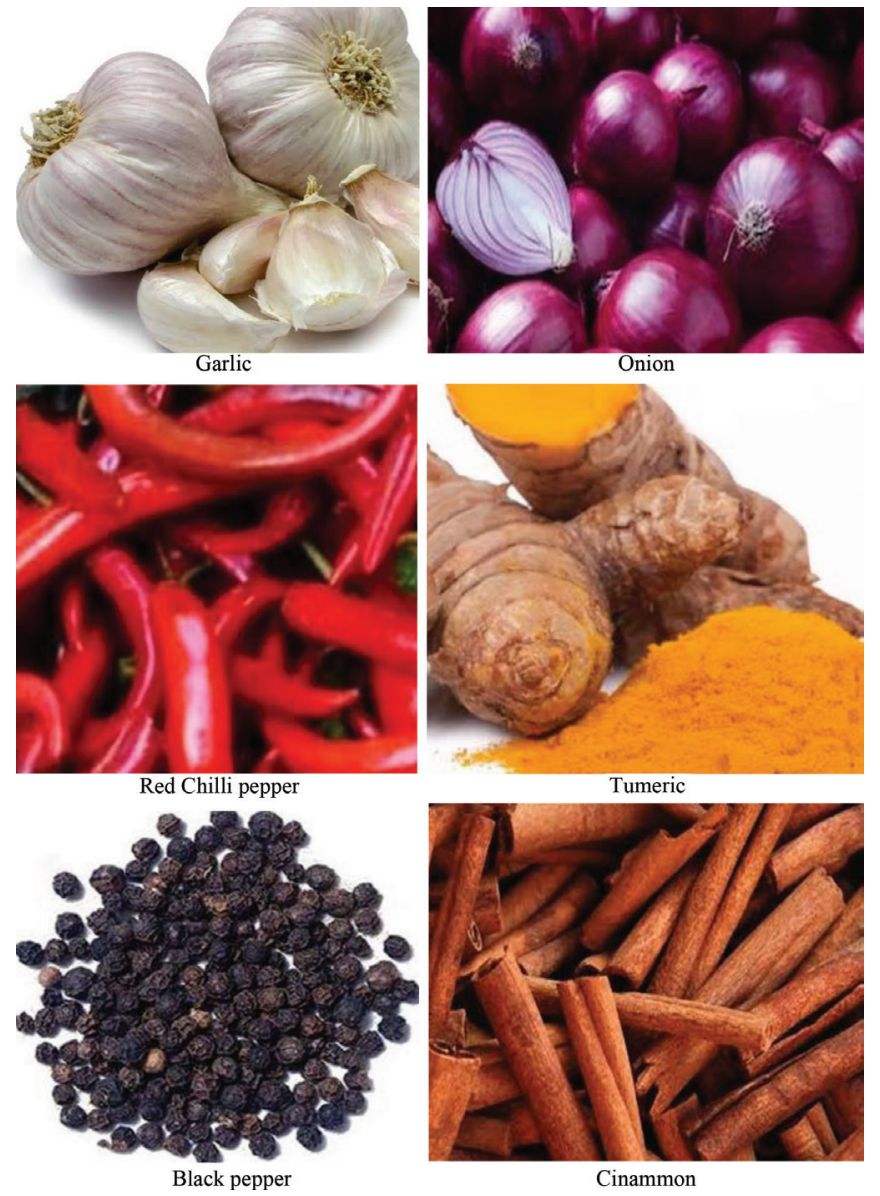

Figure 1 Pictures of some common tropical spices.

in the selected tropical spices are shown in Figure 2. The various reported medicinal importance of these phytochemicals include purgative, laxative, expectorant, carminative, diuretic, antioxidant, antimicrobial, hypolipidemic, antidiabetic, anti-inflammatory, anticarcinogenic, antihelminthic, hypocholesterolemic, antihypertensive, antidiabetic and neuroprotective effects amidst others [67,73-75]. Specifically, phytochemical compounds in spices like red chilli pepper, onion, garlic, turmeric, mustard and horseradish have been reported to possess expectorant activities [76,77]. Thus, this review shows that spices are important functional food ingredients which might mitigate and assuage the symptoms, side effects and fatality of COVID-19.

\subsection{Tropical Spices as Potent Inhibitors of SARS-CoV-2 and their Mechanisms of Action}

A very possible option for treatment of COVID-19 symptoms and its associated complications might involve the use of tropical spices which have been previously proven to be effective in the management of cold, flu and all other common viral symptoms. Previous studies have shown that the active phytochemicals, in spices are probably responsible for their observed important physiological properties coupled with synergistic effects when combined $[78,79]$. Spices contain several phytoconstituents which activates<smiles>COc1cc(/C=C/C(=O)CC(=O)/C=C/c2ccc(O)c(OC)c2)ccc1C</smiles><smiles>C=CCSS(=O)CC=C</smiles>

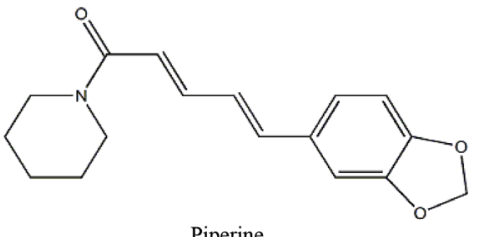

Piperine<smiles>O=C(O)/C=C/c1ccccc1</smiles>

Cinnamic acid<smiles>O=C/C=C/c1ccccc1</smiles>

Cinnamaldehyde<smiles>C=CCc1ccc(O)c(OC)c1</smiles>

Figure 2 Chemical structures of bioactive compounds in common tropical spices.

gastric receptors and thus producing an afferent reflex through the medulla of the brain. Likewise, a lesser stimulus might also activate the respiratory and cough centres in the medulla by acting on adjacent mucokinetic centre [76]. However, phytochemicals provide efferent vagal fibres to the bronchial gland and reflex activation which results in marked increase in basal respiratory tract secretion and thus leading to enhanced expectoration [77]. The reported bioactive compounds in the various spices have diverse biological activities. The red chilli pepper owes its stimulatory qualities to the active compound, capsaicin. It has been used in recent years in the management of pulmonary nerve, malignant growth, cardiovascular and gastrointestinal disorders $[79,80]$. Another important active compound is allyl isothiocyanate from mustard and horseradish that are associated with the induction of lachrymal, nasal and respiratory gland secretion [77]. In addition, onion contains pungent sulfur volatiles compounds with stimulatory effects on lachrymal and respiratory exocrine glands. Some other active phytochemicals in spices include: curcumin and 6-gingerol in ginger $[81,82]$; allicin, ajoene and S-allylcysteine in garlic $[78,83]$ and other widely distributed flavonoids such as apigenin, quercetin, kaempferol and genistein $[84,85]$. Generally, spices act on the lungs through a gastro-pulmonary expectorant reflex and thus, they might be able to provide relief to COVID-19 patients and could also serve as prophylaxis [86]. Below are the descriptions of some spices that have proven to be highly beneficial in the treatment of flu and other viral infections such as the newly emerged COVID-19.

\subsubsection{Turmeric}

Turmeric (Curcuma longa L.) is an important spice belonging to the family of ginger (Zingiberaceae) and natively grown in India, 
Southeast Asia and Africa for its rhizome. The crude extracts of turmeric rhizome has been reported to possess anti-inflammatory, anti-diabetic, hepatoprotective, hypolipidemic, anti-diarrhoeal, anti-asthmatic and anti-cancerous effects [87]. This plant rhizomes contain several secondary metabolites (e.g. curcuminoids, sesquiterpenes, steroids etc.) with the curcuminoid curcumin being the major bioactive substance and the main component of the yellow pigment obtained from this rhizome [88]. Curcumin is a symmetric molecule of two phenol rings; diferuloylmethane and diarylheptanoid connected by $\alpha, \beta$-unsaturated carbonyl groups [89]. It is approved as a food additive and also functions as a food coloring agent in many processed food products such as baked goods, sweets, cheese etc. Curcumin has a broad spectrum of medicinal values ranging from anti-viral, anti-inflammatory, anti-amyloidogenic and anti-cancerous activities [75,90,91]. The antiviral activity of curcumin against several human viruses such as hepatitis viruses, influenza viruses, emerging arboviruses like the Zika virus or chikungunya virus, human immunodeficiency virus, herpes simplex virus 2 , human papillomavirus and respiratory syncytial virus have been reported. Basically, the underlying mechanisms of action of curcumin against these viruses involve acting as entry and replication inhibitors by preventing the virus from binding to ACE2 protein [89,92-94]. In the same vein, curcumin might likely act against SARS-CoV-2 due to their ability to inhibit the activity of p21-activated kinase 1, Activator Protein 1 (AP1) and transcription nuclear factor- $\kappa \mathrm{B}$ signaling pathways of COVID-19 [95]. There was high binding affinity between the chemical structure of curcumin and SARS-CoV-2 main protease, this structure-activity relationship suggest that curcumin might be able to prevent SARS-CoV-2 viral replication [96].

\subsubsection{Onion}

Onion (Allium cepa) bulb is widely grown and consumed worldwide due to its valuable and medicinal significance. The crude extracts of onion were reported to be effective in minimizing New Castle viral infection and potato virus infection by inhibiting their entry and attachment to cells [97]. It contains three major nonvolatile and odorless cysteine sulfoxides, these are: isoalliin, methiin, and propiin. Isoalliin is the main cysteine sulfoxides, containing about $80 \%$ of the total amount while methiin and propiin are present in low amounts in onion [98,99]. Onion contains quercetin and kaempferol as its main flavonoid compounds with reports showing that these compounds affect the growth of many viruses [100] and thus, exhibiting strong antiviral activity which could also be attributed to its zalcitabine, allicin and ribavirin contents [101]. However, quercetin is the main active compound in onion with strong anti-infective and anti-replicative effect on viruses [102] like poliovirus, hepatitis viruses and influenza type A virus [103]. In addition, Chen et al. [104] reported that quercetin was able to inhibit SARS-CoV virus by targeting cellular processes, preventing its entry and attachment to host cells and also by inhibiting RNA polymerase, reverse transcriptase, integrase, protease and protein assembly which are necessary for viral replication. Quercetin could also fortify the immune system by promoting early interferons production, modulating interleukins, promoting $\mathrm{T}$ cell maturation and phagocytic activity, therefore, it could be a promising panacea for SARS-CoV-2 [105]. The molecular docking of quercetin to the main protease of SARS-CoV-2 shows high binding affinity, thus, quercetin might be able to prevent SARS-CoV-2 viral entry and replication [106].

\subsubsection{Garlic}

Garlic (Allium sativum) has been used as a medication for common colds, influenza and other kinds of infections [107,108]. Garlic clove is a potent mucolytic drug, that is, an oral mucus-loosening drug and thus classified as a mucoregulator. Therefore, it might be useful in the treatment of different respiratory conditions such as asthma, cough and other pulmonary diseases. In addition, it is rich in antioxidant compounds which could further protect the lungs [86,109]. Previous studies have proven that crude garlic extract also possesses strong antiviral properties. It has been shown to be effective against common cold virus [110], influenza A and B viral infections [111], cytomegalovirus [112,113], rhinovirus, human immunodeficiency virus, herpes simplex virus 1 [114], herpes simplex virus 2 [115], infectious bronchitis virus [116], viral pneumonia and rotavirus [102]. It is believed that crude garlic extract exerts their antiviral activity by interacting with the viral cell surface charge molecule and subsequently blocking viral entry into host cells [117]. The main phytochemicals which impart antiviral properties to garlic are the organosulfur compounds, garlic has more than 30 sulfur containing compounds with allicin being the most prominent $[115,118]$. Reports have also shown that allicin acts by blocking the release of pro-inflammatory cytokines such as interleukin- 6 and tumor necrosis factor, and by downregulating the extracellular-signal-regulated kinase/mitogen activated protein kinase signaling pathway, this could further enhance inhibition of SARS-CoV-2 viral replication in host cells membrane by preventing the virus protein maturation, its replication and further spread $[119,120]$. In addition, studies have shown that the essential oil obtained from garlic is a unique source of organosulfur compounds, most importantly, allicin, which possesses strong antioxidant, antiviral, antibacterial, antifungal, anticancer, antimicrobial, hypoglycemia, hypotension, antithrombotic, immunomodulatory and cholesterol lowering properties [121]. The high organosulfur compounds of garlic essential oil has been reported as an ACE2 inhibitor, thus, losing the host receptor, using the molecular docking method. Therefore, it could be very useful in the prevention and/or treatment of SARS-CoV-2 specifically and also in other viruses that cause flu or pneumonia [122].

\subsubsection{Red chilli pepper}

Red chilli pepper (Capsicum spp) is a popular and commonly used spice all around the world. The name, chilli, originates from Nahuatl chilli via the Spanish word chile [123]. The crude extract of red chilli pepper is being used as an alternative medicine for the treatment of inflammation, acute tonsillitis, nausea, sore throat problem and vomiting $[124,125]$. The active compound in chilli pepper is capsaicin, it is responsible for the pungency of this spice fruit. Capsaicin is an alkyl vanillylamine (capsaicinoid), a potent liberator of substances from non-adrenergic and non-cholinergic nerve terminals in the airways capable of inducing various respiratory tract effects including sneezing and the secretion of mucus [126]. Gonzalez-Paz et al. [96] reported that the molecular docking studies of capsaicin with SARSCoV-2 main protease generated a more stable thermodynamic 
structures when compared with some other compounds, this suggests that capsacin could be a good inhibitor of proteases, therefore, preventing viral replication of SARS-CoV-2.

\subsubsection{Black Pepper}

Black pepper (Piper nigrum Linn) belongs to the family Piperaceae, sometimes called Long Pepper. It is a flowering vine cultivated for its fruit which is used as a spice often after drying [127]. The crude extract of black pepper fruits had antiviral activity against Vesicular stomatitis Indiana virus and Human para influenza virus in HeLa cell line. The antiviral action was attributed to its ability to fracture, disrupt and completely collapse the plasma membrane of pathogens, thereby, increasing cell permeabilization and disruption of membrane integrity [128]. The main active compound is piperine which has a similar action to that of capsaicin. It confers the pungent pepper taste and produce salivation and numbness of the mouth effects. The crude extracts of black pepper fruit is used in the treatment of digestive tract and respiratory tract related diseases and also improves the bioavailabity and adsorption of drugs and other phytochemical compounds such curcumin and catechin $[129,130]$. Previous researches had reported that black pepper is a powerful anti-oxidant that could be used to treat asthma, colon toxins, bronchitis, influenza, sinus, congestion, chronic indigestion and fever $[131,132]$. They act by clearing up colds in the chest and lung via bringing out of unwanted mucous and phlegm. Piperine prevents viral infections via inhibition of its entry and attachment to host cells, thus, they could be beneficial in the treatment of SARCoV-2 [133-135]. The chemical structure-activity relationships of piperine and SARS-CoV-2 main protease indicated high binding affinity, thus, it might be able to prevent viral replication [96].

\subsubsection{Cinnamon}

Cinnamon (Cinnamommum spp) is an aromatic tree belonging to the family, Lauraceae. It is one of the most widely studied flowering families which comprises of about 250 species. They are evergreen trees that are widely cultivated for its bark which is used as spice in Asia, Australia, South America, Africa and Europe $[136,137]$. The crude extract of cinnamon bark provides relieve from various lung-related disorders such as pneumonia, infectious disease and malignant pleural effusion [138,139]. Likewise, the bark extracts are used in the treatment of fever, inflammation, influenza, the common cold, cough, diarrhea, nausea and pain [136]. In addition, its extract has anti-RNA viral effects and inhibited the wild type SARS infection, in vitro possibly by blocking cell entry via endocytosis [140]. The oil of cinnamon contains cinnamaldehyde and cinnamic acid-agents (45-65\% of the essential oil) with strong antiviral, antibacterial, antifungal, anticardiovascular, anticancer, anti-inflammatory, antiulcer, antidiabetes, antihypertensive, antioxidant and cholesterol and lipid-lowering properties [141-143]. Eugenol is contained as a second major constituent that contributes significantly to the biological activity of cinnamon [144]. These compounds inhibits viral protease enzyme and thus prevents processing of polypeptides which is necessary for viral replication [145]. The in silico molecular docking studies of phytochemical compounds from cinnamon indicated that they are strong inhibitors of the main protease enzyme and S glycoprotein of
SARS-CoV-2, therefore, these compounds of natural origin have been proposed to be sources of reliable medication to combat COVID-19 [146].

\section{CONCLUSION}

This review reports the medicinal benefits of few tropical spices that man has used for many years in the treatment of several ailments especially respiratory disorders. It discusses their distinct bioactive compounds and the various biochemical pathways that these medicinal plants may target in order to reduce respiratory disease burden. This could make them potent inhibitors of SARS-CoV-2 and thereby providing treatment regimen for COVID-19. Thus, it is recommended that spices should become part of our major food ingredients in order to protect our lungs, boost our immunity and prevent SARS-CoV 2 infection. However, further screening of these already known antiviral medicinal plants might be very vital.

\section{CONFLICTS OF INTEREST}

The authors declare they have no conflicts of interest.

\section{AUTHORS' CONTRIBUTION}

AAO contributed in conception, design and review. OOH contributed in investigation, drafting and writing. OG contributed in supervision, editing and critical review.

\section{REFERENCES}

[1] Guarner J. Three emerging coronaviruses in two decades: the story of SARS, MERS, and now COVID-19. Am J Clin Pathol 2020;153:420-1.

[2] Jiang S, Shi Z, Shu Y, Song J, Gao GF, Tan W, et al. A distinct name is needed for the new coronavirus. Lancet 2020;395:949.

[3] Gorbalenya AE, Baker SC, Baric RS, de Groot RJ, Drosten C, Gulyaeva AA, et al. The species severe acute respiratory syndromerelated coronavirus: classifying $2019-\mathrm{nCoV}$ and naming it SARSCoV-2. Nat Microbiol 2020;5:536-44.

[4] Wan Y, Shang J, Graham R, Baric RS, Li F. Receptor recognition by novel coronavirus from Wuhan: an analysis based on decadelong structural studies of SARS. J Virol 2020;94:e00127-e20.

[5] Balachandar V, Mahalaxmi I, Kaavya J, Vivek G, Ajithkumar S, Arul N, et al. COVID-19: emerging protective measures. Eur Rev Med Pharmaco 2020;24 (In Press).

[6] Elfiky AA. Anti-HCV, nucleotide inhibitors, repurposing against COVID-19. Life Sci 2020;248:117477.

[7] Stebbing J, Phelan A, Griffin I, Tucker C, Oechsle O, Smith D, et al. COVID-19: combining antiviral and anti-inflammatory treatments. Lancet Infect Dis 2020;20:400-2.

[8] Zheng M, Song L. Novel antibody epitopes dominate the antigenicity of spike glycoprotein in SARS-CoV-2 compared to SARSCoV. Cell Mol Immunol 2020;17:536-8.

[9] Moghadamtousi SZ, Nikzad S, Kadir HA, Abubakar S, Zandi K. Potential antiviral agents from marine fungi: an overview. Mar Drugs 2015;13:4520-38. 
[10] Vellingiri B, Jayaramayya K, Iyer M, Narayanasamy A, Govindasamy V, Giridharan B, et al. COVID-19: a promising cure for the global panic. Sci Total Environ 2020;725:138277.

[11] Srinivasan K. Role of Spices beyond food flavoring: nutraceuticals with multiple health effects. Food Rev Int 2005;21:167-88.

[12] Newman DJ, Cragg GM. Natural products as sources of new drugs from 1981 to 2014. J Nat Prod 2016;79:629-61.

[13] Umesh, Kundu D, Selvaraj C, Singh SK, Dubey VK. Identification of new anti-nCoV drug chemical compounds from Indian spices exploiting SARS-CoV-2 main protease as target. J Biomol Struct Dyn 2020;1-7.

[14] Cleri DJ, Ricketti, AJ, Vernaleo JR. Severe acute respiratory syndrome (SARS). Infect Dis Clin North Am 2010;24:175-202.

[15] Coronaviridae Study Group of the International Committee on Taxonomy of Viruses. The species severe acute respiratory syndrome-related coronavirus: classifying 2019-nCoV and naming it SARS-CoV-2. Nat Microbiol 2020;5:536-44.

[16] Banerjee A, Kulcsar K, Misra, V, Frieman M, Mossman K. Bats and coronaviruses. Viruses 2019;11:41.

[17] Schoeman D, Fielding BC. Coronavirus envelope protein: current knowledge. Virol J 2019;16:69.

[18] Killerby ME, Biggs HM, Haynes A, Dahl RM, Mustaquim D, Gerber SI, et al. Human coronavirus circulation in the United States 2014-2017. J Clin Virol 2018;101:52-6.

[19] Arabi YM, Balkhy HH, Hayden FG, Bouchama A, Luke T, Baillie JK, et al. Middle East respiratory syndrome. N Engl J Med 2017;376:584-94.

[20] Skariyachan S, Challapilli SB, Packirisamy S, Kumargowda ST, Sridhar VS. Recent aspects on the pathogenesis mechanism, animal models and novel therapeutic interventions for Middle East respiratory syndrome coronavirus infections. Front Microbiol 2019;10:569.

[21] Zumla A, Hui DS, Perlman S. Middle East respiratory syndrome. Lancet 2015;386:995-1007.

[22] Lu R, Zhao X, Li J, Niu P, Yang B, Wu H, et al. Genomic characterisation and epidemiology of 2019 novel coronavirus: implications for virus origins and receptor binding. Lancet 2020;395:565-74.

[23] Song Z, Xu Y, Bao L, Zhang L, Yu P, Qu Y, et al. From SARS to MERS, thrusting coronaviruses into the spotlight. Viruses 2019;11:59.

[24] Li W, Moore MJ, Vasilieva N, Sui J, Wong SK, Berne MA, et al. Angiotensin-converting enzyme 2 is a functional receptor for the SARS coronavirus. Nature 2003;426:450-4.

[25] Peiris JS, Guan Y, Yuen KY. Severe acute respiratory syndrome. Nat Med 2004;10:S88-S97.

[26] Hui DS, Azhar EI, Madani TA, Ntoumi F, Kock R, Dar O, et al. The continuing 2019-nCoV epidemic threat of novel coronaviruses to global health - The latest 2019 novel coronavirus outbreak in Wuhan, China. Int J Infect Dis 2020;91:264-6.

[27] Chan JFW, Kok KH, Zhu Z, Chu H, To KKW, Yuan S, et al. Genomic characterization of the 2019 novel human-pathogenic coronavirus isolated from a patient with atypical pneumonia after visiting Wuhan. Emerg Microbes Infect 2020;9:221-36.

[28] Habibzadeh P, Stoneman EK. The novel coronavirus: a bird's eye view. Int J Occup Environ Med 2020;11:65.

[29] Chan JFW, Yip CCY, To KKW, Tang THC, Wong SCY, Leung $\mathrm{KH}$, et al. Improved molecular diagnosis of COVID-19 by the novel, highly sensitive and specific COVID-19-RdRp/Hel realtime reverse transcription-PCR assay validated in vitro and with clinical specimens. J Clin Microbiol 2020;58:e00310-e20.

[30] Huang C, Wang Y, Li X, Ren L, Zhao J, Hu Y, et al. Clinical features of patients infected with 2019 novel coronavirus in Wuhan, China. Lancet 2020;395:497-506.

[31] Heymann DL, Shindo N; WHO Scientific and Technical Advisory Group for Infectious Hazards. COVID-19: what is next for public health? Lancet 2020;395:542-45.

[32] Li YC, Bai WZ, Hashikawa T. The neuroinvasive potential of SARS-CoV2 may play a role in the respiratory failure of COVID19 patients. J Med Virol 2020;92:552-5.

[33] Matthew A. Lost smell and taste hint COVID-19 can target the nervous system. The Scientist 2020.

[34] Chen N, Zhou M, Dong X, Qu J, Gong F, Han Y, et al. Epidemiological and clinical characteristics of 99 cases of 2019 novel coronavirus pneumonia in Wuhan, China: a descriptive study. Lancet 2020;395:507-13.

[35] Siu YL, Teoh KT, Lo J, Chan CM, Kien F, Escriou N, et al. The $\mathrm{M}, \mathrm{E}$, and $\mathrm{N}$ structural proteins of the severe acute respiratory syndrome coronavirus are required for efficient assembly, trafficking, and release of virus-like particles. J Virol 2008;82:11318-30.

[36] Walls AC, Park YJ, Tortorici MA, Wall, A, McGuire AT, Veesler D. Structure, function, and antigenicity of the SARS-CoV-2 spike glycoprotein. Cell 2020;181:281.e6-92.e6.

[37] Zumla A, Chan JFW, Azhar EI, Hui DSC, Yuen KY. Coronaviruses - drug discovery and therapeutic options. Nat Rev Drug Discov 2016;15:327-47.

[38] Yin Y, Wunderink RG. MERS, SARS and other coronaviruses as causes of pneumonia. Respirology 2018;23:130-7.

[39] Tai W, He L, Zhang X, Pu J, Voronin D, Jiang S, et al. Characterization of the receptor-binding domain (RBD) of 2019 novel coronavirus: implication for development of RBD protein as a viral attachment inhibitor and vaccine. Cell Mol Immunol 2020;17:613-20.

[40] Zhang L, Lin D, Sun X, Curth U, Drosten C, Sauerhering L, et al. Crystal structure of SARS-CoV-2 main protease provides a basis for design of improved a-ketoamide inhibitors. Science 2020;368: 409-12.

[41] Phan T. Novel coronavirus: from discovery to clinical diagnostics. Infect Genet Evo 2020;79:104211.

[42] Zhao Y, Zhao Z, Wang Y, Zhou Y, Ma Y, Zuo W. Single-cell RNA expression profiling of ACE2, the receptor of SARS-CoV-2. BioRxiv 202:756-9.

[43] Roberts A, Deming D, Paddock CD, Cheng A, Yount B, Vogel $\mathrm{L}$, et al. A mouse-adapted SARS-coronavirus causes disease and mortality in BALB/c mice. PLoS Pathol 2007;3:e5.

[44] Tikellis C, Thomas MC. Angiotensin-converting enzyme 2 (ACE2) is a key modulator of the renin angiotensin system in health and disease. Int J Pept 2012;2012:256294.

[45] Patel VB, Zhong JC, Grant MB, Oudit GY. Role of the ACE2/ Angiotensin 1-7 axis of the renin-angiotensin system in heart failure. Circ Res 2016;118:1313-26.

[46] Wang D, Hu B, Hu C, Zhu F, Liu X, Zhang J, et al. Clinical characteristics of 138 hospitalized patients with 2019 novel coronavirus-infected pneumonia in Wuhan, China. JAMA 2020;323: 1061-9. 
[47] Wang K, Gheblawi M, Oudit GY. Angiotensin converting enzyme 2: a double-edged sword. Circulation 2020;142:426-8.

[48] South AM, Shaltout HA, Washburn LK, Hendricks AS, Diz DI, Chappell MC. Fetal programming and the angiotensin-(1-7) axis: a review of the experimental and clinical data. Clin Sci 2019;133:55-74.

[49] Sampaio WO, dos Santos RAS, Faria-Silva R, da Mata Machado LT, Schiffrin EL, Touyz RM. Angiotensin-(1-7) through receptor Mas mediates endothelial nitric oxide synthase activation via Akt-dependent pathways. Hypertension 2007;49:185-92.

[50] Arnold AC, Gallagher PE, Diz DI. Brain renin-angiotensin system in the nexus of hypertension and aging. Hypertens Res 2013;36:5-13.

[51] Yousif MHM, Benter IF, Diz DI, Chappell MC. Angiotensin-(1-7)dependent vasorelaxation of the renal artery exhibits unique angiotensin and bradykinin receptor selectivity. Peptides 2017;90:10-16.

[52] Tipnis SR, Hooper NM, Hyde R, Karran E, Christie G, Turner AJ. A human homolog of angiotensin-converting enzyme: cloning and functional expression as a captopril-insensitive carboxypeptidase. J Biol Chem 2000;275:33238-43.

[53] Gralinski LE, Menachery VD. Return of the coronavirus: 2019nCoV. Viruses 2020;12:135.

[54] Paraskevis D, Kostaki EG, Magiorkinis G, Panayiotakopoulos G, Sourvinos G, Tsiodras S. Full-genome evolutionary analysis of the novel corona virus (2019-nCoV) rejects the hypothesis of emergence as a result of a recent recombination event. Infect Genet Evol 2020;79:104212.

[55] Imai Y, Kuba K, Rao S, Huan Y, Guo F, Guan B, et al. Angiotensinconverting enzyme 2 protects from severe acute lung failure. Nature 2005;436:112-16.

[56] Kuba K, Imai Y, Rao S, Gao H, Guo F, Guan B, et al. A crucial role of angiotensin converting enzyme 2 (ACE2) in SARS coronavirusinduced lung injury. Nat Med 2005;11:875-9.

[57] Ye R, Liu Z. ACE2 exhibits protective effects against LPS-induced acute lung injury in mice by inhibiting the LPS-TLR4 pathway. Exp Mol Pathol 2019;113:104350.

[58] Zhou F, Yu T, Du R, Fan G, Liu Y, Liu Z, et al. Clinical course and risk factors for mortality of adult inpatients with COVID-19 in Wuhan, China: a retrospective cohort study. Lancet 2020;395:1054-62.

[59] Inciardi RM, Lupi L, Zaccone G, Italia L, Raffo M, Tomasoni D, et al. Cardiac involvement in a patient with Coronavirus disease 2019 (COVID-19). JAMA Cardiol 2020;5:819-24.

[60] Guo T, Fan Y, Chen, M, Wu X, Zhang L, He T, et al. Cardiovascular implications of fatal outcomes of patients with coronavirus disease 2019 (COVID-19). JAMA Cardiol 2020;5:811-18.

[61] Reich HN, Oudit GY, Penninger JM, Scholey JW, Herzenberg AM. Decreased glomerular and tubular expression of ACE2 in patients with type 2 diabetes and kidney disease. Kidney Int 2008;74:1610-16.

[62] Duan Y, Prasad R, Feng, D, Beli E, Calzi SL, Longhini ALF, et al. Bone marrow-derived cells restore functional integrity of the gut epithelial and vascular barriers in a model of diabetes and ACE2 deficiency. Circ Res 2019;125:969-88.

[63] Hashimoto T, Perlot T, Rehman A, Trichereau J, Ishiguro H, Paolino M, et al. ACE2 links amino acid malnutrition to microbial ecology and intestinal inflammation. Nature 2012;487:477-81.

[64] Chan JFW, Yuan S, Kok KH, To KKW, Chu H, Yang J, et al. A familial cluster of pneumonia associated with the 2019 novel coronavirus indicating person-to-person transmission: a study of a family cluster. Lancet 2020;395:514-23.

[65] Huang C, Wang Y, Li X, Ren L, Zhao J, Hu Y, et al. Clinical features of patients infected with 2019 novel coronavirus in Wuhan, China. Lancet 2020;395:497-506.

[66] South AM, Diz D, Chappell MC. COVID-19, ACE2 and the cardiovascular consequences. Am J Physiol Heart Circ Physiol 2020;318:H1084-H90.

[67] Adefegha SA, Oboh G. Water extractable phytochemicals from some Nigerian spices inhibit Fe2+- induced lipid peroxidation in rat's brain - in vitro. J Food Process Technol 2011;2:1-6.

[68] Aboubakr HA, Nauertz A, Luong NT, Agrawal S, El-Sohaimy SAA, Youssef MM, et al. In vitro antiviral activity of clove and ginger aqueous extracts against feline calicivirus, a surrogate for human norovirus. J Food Prot 2016;79:1001-12.

[69] Manay SN, Shadaskarswamy M. Foods, facts and principles. New Delhi: New Age International Pvt. Ltd.; 1999, pp. 321-34.

[70] Uma Pradeep K, Geervani P, Eggum BO. Common Indian spices: nutrient composition, consumption and contribution to dietary value. Plant Foods Hum Nutr 1993;44:137-48.

[71] Srinivasan K, Sambaiah K, Chandrasekhara N. Spices as beneficial hypolipidemic food adjuncts: a review. Food Rev Int 2004;20:187-220.

[72] Shan B, Cai YZ, Sun M, Corke H. Antioxidant capacity of 26 spice extracts and characterization of their phenolic constituents. J Agric Food Chem 2005;53:7749-59.

[73] Kong B, Zhang H, Xiong YL. Antioxidant activity of spice extracts in a liposome system and in cooked pork patties and the possible mode of action. Meat Sci 2010;85:772-8.

[74] Mann A. Biopotency role of culinary spices and herbs and their chemical constituents in health and commonly used spices in Nigerian dishes and snacks. Afr J Food Sci 2011;5:111-24.

[75] Bhagya HP, Raveendra YC. Mulibeneficial uses of spices: a brief review. Acta Sci Nutr Health 2017;1:3-6.

[76] Boyd EM. Expectorants and respiratory tract fluid. Pharmacol Rev 1954;6:521-42.

[77] Dorsch W, Adam O, Weber J, Ziegeltrum T. Anti-asthmatic effects of onion extracts-detection of benzyl-and other isothiocyanates (mustard oils) as anti-asthmatic compounds of plant origin. Eur Pharmacol 1984;107:17-24.

[78] Dirsch VM, Kiemer AK, Wagner H, Vollmar AM. Effect of allicin and ajoene, two compounds of garlic, on inducible nitric oxide synthase. Atherosclerosis 1998;139:333-9.

[79] Kim CS, Kawada T, Kim BS, Han IS, Choe SY, Kurata T, et al. Capsaicin exhibits anti-inflammatory property by inhibiting IkB-a degradation in LPS-stimulated peritoneal macrophages. Cell Signal 2003;15:299-306.

[80] Luo XJ, Peng J, Li YJ. Recent advances in the study on capsaicinoids and capsaicinoids. Eur J Pharmacol 2011;650:1-7.

[81] Chan MM, Ho CT, Huang HI. Effects of three dietary phytochemicals from tea, rosemary and turmeric on inflammationinduced nitrite production. Cancer Lett 1995;96:23-9.

[82] Ippoushi K, Azuma K, Ito H, Horie H, Higashio H. [6]-Gingerol inhibits nitric oxide synthesis in activated J774.1 mouse macrophages and prevents peroxynitrite-induced oxidation and nitration reactions. Life Sci 2003;73:3427-37.

[83] Kim KM, Chun SB, Koo MS, Choi WJ, Kim TW, Kwon YG, et al. Differential regulation of $\mathrm{NO}$ availability from macrophages and 
endothelial cells by the garlic component s-allyl cysteine. Free Radic Bio Med 2001;30:747-56.

[84] Liang YC, Huang YT, Tsai SH, Lin-Shiau SY, Chen CF, Lin JK. Suppression of inducible cyclooxygenase and inducible nitric oxide synthase by apigenin and related flavonoids in mouse macrophages. Carcinogenesis 1999;20:1945-52.

[85] Chen YC, Shen SC, Lee WR, Hou WC, Yang LL, Lee TJF. Inhibition of nitric oxide synthase and inhibitors and lipopolysaccharide induced indicible NOS and cyclooxygenase- 2 gene expressions by rutin, quercetin, and quercetin pentaacetate in RAW 264.7 macrophages. J Cell Biochem 2001;82: 537-48.

[86] Ziment I. Possible mechanisms of action of traditional oriental drugs for bronchitis. In: Chang HM, Yeung HW, Tso WW, Koo A, editors. Advances in Chinese medicinal materials research. Singapore: World Scientific Publishing Co.; 1985, pp. 193-202.

[87] Oladele JO, Oyeleke OM, Awosanya OO, Oladele TO. Effect of Curcuma longa (turmeric) against Potassium bromateinduced cardiac oxidative damage, hematological and lipid profile Alterations in rats. Singapore J Sci Res 2020;10:8-15.

[88] Omosa LK, Midiwo JO, Kuete V. "Curcuma longa," in therapeutic potential against metabolic, inflammatory, infectious and systemic diseases. In: Kuete V, editor. Medicinal spices and vegetables from Africa. Cambridge, MA: Academic Press; 2017, pp. 425-35.

[89] Praditya D, Kirchhoff L. Brüning J, Rachmawati H, Steinmann J, Steinmann E. Anti-infective properties of the golden spice curcumin. Front Microbiol 2019;10:912.

[90] Hatcher H, Planalp R, Cho J, Torti FM, Torti SU. Curcumin: from ancient medicine to current clinical trials. Cell Mol Life Sci 2008;65:1631-52.

[91] Bachmeier BE, Killian PH. Melchart D. The role of curcumin in prevention and management of metastatic disease. Int J Mol Sci 2018;19:1716.

[92] Obata K, Kojima T, Masaki T, Okabayashi T, Yokota S, Hirakawa $\mathrm{S}$, et al. Curcumin prevents replication of respiratory syncytial virus and the epithelial responses to it in human nasal epithelial cells. PLoS One 2013;8:e70225.

[93] Yang XX, Li CM, Huang CZ. Curcumin modified silver nanoparticles for highly efficient inhibition of respiratory syncytial virus infection. Nanoscale 2016;8:3040-8.

[94] Yang XX, Li CM, Li YF, Wang J, Huang CZ. Synergistic antiviral effect of curcumin functionalized graphene oxide against respiratory syncytial virus infection. Nanoscale 2017;9:16086-92.

[95] Nemati M, Asl ER, Pouya FD, Rasmi Y. Curcumin, an inhibitor of PAK1, potential treatment for COVID-19. J Infect 2020;3: $1-3$.

[96] Gonzalez-Paz LA, Lossada CA, Moncayo LS, Romero F, Paz JL, Vera-Villalobos J, et al. Theoretical molecular docking study of the structural disruption of the viral 3CL-protease of COVID19 Induced by binding of capsaicin, piperine and curcumin part 1 : a comparative study with chloroquine and hydrochloroquine two antimalaric drugs. Res Square 2020;1-18.

[97] Mohamed EF. Antiviral properties of garlic cloves juice compared with onion bulbs juice against potato virus Y (PVY). J Am Sci 2010;6:302-10.

[98] Lawson LD. Garlic: a review of its medicinal effects and indicated active compounds. In: Phytomedicines of Europe. Chemistry and biological activity. Series 691. Washington, DC: American Chemical Society; 1998, pp. 176-209.
[99] Jones MG, Hughes J, Tregova A, Milne J, Tomsett AB, Collin HA. Biosynthesis of the flavour precursors of onion and garlic. J Exp Bot 2004;55:1903-18.

[100] Kumar S, Pandey AK. Chemistry and biological activities of flavonoids: an overview. Scientific World Journal 2013;2013:162750.

[101] Chen CH, Chou TW, Cheng LH, Ho CW. In vitro anti-adenoviral activity of five Allium plants. J Taiwan Inst Chem Eng 2011;42:228-32.

[102] Neha S. Efficacy of garlic and onion against virus. Int J Res Pharm Sci 2019;10:3578-86.

[103] Castrillo JL, Carrasco L. Action of 3-methylquercetin on poliovirus RNA replication. J Virol 1987;61:3319-21.

[104] Chen L, Li J, Luo C, Liu H, Xu W, Chen G, et al. Binding interaction of quercetin-3-beta-galactoside and its synthetic derivatives with SARS-CoV 3CL(pro): structure-activity relationship studies reveal salient pharmacophore features. Bioorg Med Chem 2006;14:8295-306.

[105] Colunga-Biancatelli RML, Berrill M, Catravas JD, Marik PE. Quercetin and vitamin C: an experimental, synergistic therapy for the prevention and treatment of SARS-CoV-2 related disease (COVID-19). Front Immunol 2020;11:1451.

[106] Azam MNK, Al Mahamud R, Hasan A, Jahan R, Rahmatullah M. Some home remedies used for treatment of COVID-19 in Bangladesh. J Med Plants Stud 2020;8:27-32.

[107] Najjaa H, Neffati M, Zouari S, Ammar E. Essential oil composition and antibacterial activity of different extracts of Allium roseum L., a North African endemic species. C R Chem 2007;10:820-6.

[108] Romeilah RM, Fayed SA, Mahmoud GI. Chemical compositions, antiviral and antioxidant activities of seven essential oils. J Appl Sci Res 2010;6:50-62.

[109] Travis J. Oxidants and antioxidants in the lung. Am Rev Respir Dis 1987;135:773-4.

[110] Josling P. Preventing the common cold with a garlic supplement: a double-blind, placebo-controlled survey. Adv Ther 2001;18:189-93.

[111] Fenwick GR, Hanley AB. The genus allium - part 1. C R C Crit Rev Food Sci Nutr 1985;22:199-271.

[112] Meng Y, Lu D, Guo N, Zhang L, Zhou G. Anti-HCMV effect of garlic components. Virol Sin 1993;8:147-50.

[113] Nai-Lan G, Cao-Pei L, Woods GL, Reed E, Gui-Zhen Z, Li-Bi $Z$, et al. Demonstration of antiviral activity of garlic extract against human cytomegalovirus in vitro. Chinese Med J 1993;106:93-6.

[114] Tsai Y, Cole LL, Davis LE, Lockwood SJ, Simmons V, Wild GC. Antiviral properties of garlic: in vitro effects on influenza B, herpes simplex and coxsackie viruses. Planta Med 1985;51:460-1.

[115] Weber ND, Andersen DO, North JA, Murray BK, Lawson LD, Hughes BG. In vitro virucidal effects of Allium sativum (Garlic) extract and compounds. Planta Med 1992;58:417-23.

[116] Shojai TM, Langeroudi AG, Karimi V, Barin A, Sadri N. The effect of Allium sativum (Garlic) extract on infectious bronchitis virus in specific pathogen free embryonic egg. Avicenna J Phytomed 2016;6:267-458.

[117] Rouf R, Uddin SJ, Sarker DK, Islam MT, Ali ES, Shilpi JA, et al. Antiviral potential of garlic (Allium sativum) and its organosulfur compounds: a systematic update of pre-clinical and clinical data. Trends Food Sci Technol 2020;104:219-34.

[118] Hughes B, Murray B, North J, Lawson LD. Antiviral constituents from Allium sativum. Planta Med 1989;55:114. 
[119] Shin JH, Ryu JH, Kang MJ, Hwang CR, Han J, Kang D. Shortterm heating reduces the anti-inflammatory effects of fresh raw garlic extracts on the LPS-induced production of NO and proinflammatory cytokines by downregulating allicin activity in RAW 264.7 macrophages. Food Chem Toxicol 2013;58:545-51.

[120] Gu X, Wu H, Fu P. Allicin attenuates inflammation and suppresses HLA-B27 protein expression in ankylosing spondylitis mice. Biomed Res Int 2013;2013:171573.

[121] Chekki RZ, Snoussi A, Hamrouni I, Bouzouita N. Chemical composition, antibacterial and antioxidant activities of Tunisian garlic (Allium sativum) essential oil and ethanol extract. Mediterr J Chem 2014;3:947-56.

[122] Thuy BTP, My TTA, Hai NTT, Hieu LT, Hoa TT, Thi Phuong Loan $\mathrm{H}$, et al. Investigation into SARS-CoV-2 resistance of compounds in garlic essential oil. ACS Omega 2020;5:8312-20.

[123] Maqsood S, Singh P, Samoon MH, Munir K. Emerging role of immunostimulants in combating the disease outbreak in aquaculture. Int Aquat Res 2011;3:147-63.

[124] Szallasi A. Piperine: researchers discover new flavor in an ancient spice. Trends Pharmacol Sci 2005;26:437-9.

[125] Ravindran PN, Nirmal Babu K, Sivaraman K. Turmeric. The golden spice of life. In: Turmeric. The Genus Curcuma. Boca Raton, FL, USA: CRC Press; 2007, pp. 1-14.

[126] Rogers OF, Barnes PJ. Opioid inhibition of neurally mediated mucus secretion in human bronchi. Lancet 1989;333:930-2.

[127] Kirtikar KR, Basu BD. Indian medicinal plants. 3rd ed. Dehradun, India: International Book Distributors; 1987, pp. 2128-9.

[128] Zou L, Hu YY, Chen WX. Antibacterial mechanism and activities of black pepper chloroform extract. J Food Sci Technol 2015;52:8196-203.

[129] Ravindran PN. Black Pepper: Piper nigrum. Series: Medicinal and Aromatic Plants - Industrial Profiles. Centre for Medicinal Plants Research. Kerala, India: CRC Press; 2000, pp. 1-526.

[130] Singletary K. Black pepper: overview of health benefits. Food Sci 2010;45:43-7.

[131] Council of Scientific and Industrial Research. The Wealth of India: a dictionary of Indian Raw Materials and Industrial Products. Vol. 11. New Delhi, India: Council of Scientific and Industrial Research; 1949;476-7.

[132] Srinivasan K. Plant foods in the management of diabetes mellitus: spices as beneficial antidiabetic food adjuncts. Int J Food Sci Nutr 2005;56:399-414.

[133] Karpińska M, Borowski J, Danowska-Oziewicz M. The use of natural antioxidants in ready-to-serve food. Food Chem 2001;72:5-9.
[134] Fragiska M. Wild and cultivated vegetables, herbs and spices in Greek antiquity. Environ Archaeol 2005;10:73-82.

[135] Sheila G. Herbs and spices for good health; 2007. Available from: www.herbsspices.com.

[136] Cheng BC. A review of cinnamon. Zhong Cao Yao 1983;14:134.

[137] Shen Y, Jia LN, Honma N, Hosono T, Ariga T, Seki T. Beneficial effects of cinnamon on the metabolic syndrome, inflammation, and pain, and mechanisms underlying these effects - a review. J Tradit Complement Med 2012;2:27-32.

[138] Lai K, Shen H, Zhou X, Qiu Z, Cai S, Huang K, et al. Clinical practice guidelines for diagnosis and management of coughChinese Thoracic Society (CTS) Asthma Consortium. J Thorac Dis 2018;10:6314-51.

[139] Townsend EA, Siviski ME, Zhang Y, Xu C, Hoonjan B, Emala CW. Effects of ginger and its constituents on airway smooth muscle relaxation and calcium regulation. Am J Respir Cell Mol Biol 2013;48:157-63.

[140] Zhuang M, Jiang H, Suzuki Y, Lia X, Xiao P, Tanaka T, et al. Procyanidins and butanol extract of Cinnamomi cortex inhibit SARS-CoV infection. Antiviral Rev 2009;82:73-81.

[141] Premanathan M, Rajendran S, Ramanathan T, Kathiresan K, Nakashima H, Yamamoto N. A survey of some Indian medicinal plants for anti-human immunodeficiency virus (HIV) activity. Indian J Med Res 2000;112:73-7.

[142] Hayashi K, Imanishi N, Kashiwayama Y, Kawano A, Terasawa $\mathrm{K}$, Shimada $\mathrm{Y}$, et al. Inhibitory effect of cinnamaldehyde, derived from Cinnamomi cortex, on the growth of influenza A/ $\mathrm{PR} / 8$ virus in vitro and in vivo. Antiviral Res 2007;74:1-8.

[143] Connell BJ, Chang SY, Prakash E, Yousfi R, Mohan V, Posch $\mathrm{W}$, et al. A cinnamon-derived procyanidin compound displays anti-HIV-1 activity by blocking heparan sulfateand co-receptor- binding sites on gp120 and reverses T cell exhaustion via impeding Tim-3 and PD-1 upregulation. PLoS One 2016;11:e0165386.

[144] Isogai A, Murakoshi S, Suzuki A, Tamura S. Chemistry and biological activities of cinnzeylanine and cinnzeylanol, new insecticidal substances from Cinnamonum zeylanicum nees. Agric Biol Chem 1977;41:1779-84.

[145] Channe Gowda D, Sarathy C. Structure of an 1-arabino-d-xylan from the bark of Cinnamomum zeylanicum. Carbohydrate Res 1987;166:263-9.

[146] Prasanth DSNBK, Murahari M, Chandramohan V, Panda SP, Atmakuri LR, Guntupalli C. In silico identification of potential inhibitors from Cinnamon against main protease and spike glycoprotein of SARS CoV-2. J Biomol Struct Dyn 2020;1-15. 